\title{
$\mathrm{Mg}$ 基 LPSO相におけるキンク帯形成の結晶塑性解析
}

\section{Crystal plasticity finite element analysis of kink banding in Mg-based LPSO phase}

\author{
眞山 剛 ${ }^{1 *} \cdot$ 大橋 鉄也 $^{2}$ \\ Tsuyoshi MAYAMA ${ }^{1 *}$ and Tetsuya OHASHI ${ }^{2}$
}

\section{1. はじめに}

長周期積層構造（LPSO）相を含有するマグネシウム（Mg） 合金（LPSO型Mg合金）は，従来の Mg 合金と比較して著し く高い強度を示すことから, Mg 合金の構造材料としての応 用を拡大し得る軽金属材料である ${ }^{1)-3)}$ 。具体的には，急速凝 固 $\mathrm{Mg}_{97} \mathrm{Zn}_{1} \mathrm{Y}_{2}$ 合金の固化成型材では室温降伏応力 $600 \mathrm{MPa}$ 以 上 $^{1)}$, 通常の溶解鋳造後に押出加工を施した Mg-Zn-Y系合金 でも室温降伏応力は $350 \mathrm{MPa}$ を大き超える ${ }^{2)}$ 。多くの商用 $\mathrm{Mg}$ 合金素形材の室温降伏応力が $250 \mathrm{MPa}$ に満たない4)ことを 考えると, LPSO型 $\mathrm{Mg}$ 合金が $\mathrm{Mg}$ 合金として極めて高強度で あることがわかる。LPSO型Mg合金の強度発現機構について の理解は未だに不十分であるが，他の $\mathrm{Mg}$ 合金と比較した際 の組織的特徴として, 塑性加工後の LPSO 相には多量のキン ク帯が導入されている点が挙げられ，その導入により強度が 著しく上昇し得ることを示唆する実験結果が報告されてい

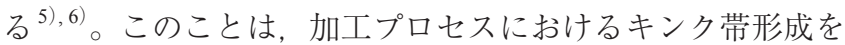
積極的に活用した材料特性制御の可能性を示すものであり, その実現にはLPSO相におけるキンク帯形成機構と力学特性 発現機構の理解が必要である。

キンク帯とは，塑性変形の局所化により形成される変形带 の一形態であり, 活動変形機構の剪断方向と垂直に局所化し た領域である ${ }^{7)}$ 。このような変形の局所化は，特に塑性異方 性の強い材料に扔いて顕著であり，最密六方晶（HCP）金 属 ${ }^{8-13)}$, 纎維強化複合材料 ${ }^{14)-17)}$, 層状構造を持つ材料 ${ }^{18-20)}$ 等において頻繁に観察され，大きな結晶方位変動を伴うこと も特徵である。また，塑性異方性が比較的弱い立方晶金属の 単結晶に打いても変形初期に扔いてキンク帯が形成されるこ とが古くから知られているが ${ }^{21-23)}$ ，そのような場合は大き な粒内方位差を伴う顕著な局所化にまで発達することはほと んどない。

キンク帯の形成過程の詳細や影響因子を系統的に調査する ためには, 結晶粒内の不均一変形を表現可能な数值解析手法 が有用である。特に材料の微視的変形機構を陽に考慮した結 晶塑性構成則を有限要素法に導入した結晶塑性有限要素 法 ${ }^{24)-26)}$ は，すべりの局所化により発達するキンク帯の形成 を表現可能であり，FCC 単結晶を対象とした解析が実施され
ている ${ }^{27), 28)}$ 。また, 圧縮負荷を受けるHCP 単結晶やLPSO相 単結晶を想定した数值解析も報告されており, その微視的素 過程と影響因子が明らかになりつつある ${ }^{29), 30) 。 ~}$

本稿では，これまで比較的報告の少ない引張負荷および剪 断負荷を受ける Mg 基 LPSO 相単結晶におけるキンク帯形成 に関する結晶塑性有限要素解析の結果について紹介する。

\section{2. 引張負荷を受ける単結晶におけるキンク帯形 成・成長解析}

本章では, マイクロ材料試験法 ${ }^{31-33)} に よ り$ 実施された 18R-LPSO構造を持つ Mg-Zn-Y 合金単結晶の引張試験結果を 紹介した後，実験に対応する結晶塑性解析の結果を示す ${ }^{34)}$ 。

図 1 (a) は，マイクロ材料試験に使用した標点間の断面積 $20 \times 20 \mu \mathrm{m}$ を持つマイクロ材料試験片の光学顕微鏡写真を示 している。この試料を図中の模式図に示すように, [0001] 方 向から [1120］方向に140傾いた方向を負荷軸として引張試験 を実施した。図1(b) はマイクロ材料試験により得られた応 カーひずみ曲線であり, 応力が $160 \mathrm{MPa}$ 程度に到達すると急 激に低下し，さららに急激に応力が増減した後，50\%を超える 公称ひずみまで 80 100 MPa程度の流動応力で変形する挙動 を示している。図 1 (c) は $6.4 \%$ 変形時の形状を示す光学顕微 鏡像であり, 試料表面には引張方向と $33^{\circ}$ 傾いた変形の集中 領域が確認されている。ここで，変形の集中が底面すべり系 の活動により生じたキンク带に対応するものであり，その境 界が対称傾角粒界であると仮定すると, 図 1(d) に示す模式 図のように表現することができる。また，このように変形初 期に㧍いてすべりが局所化しているにも関わらず，図1(b)に 示すように公称ひずみ $50 \%$ を超える大きな延性を発現して おり，57\%変形後の試料は図1(e) に示すような形状に変化 している。引張変形に打いてすべりが局所化してネッキング が生じた場合，局所化箇所が硬化しなければ，さらなるすべ りの蓄積が局所化領域で生じて破断に至る。局所化箇所の硬 化は，転位の蓄積による加工硬化，もしくは結晶格子回転に より活動すべり系の分解剪断応力が下がる幾何学的硬化の可 能性があるが，以下では，後者の可能性について本実験に対 応する数值解析の結果を示し, 実験的に観察された変形挙動 をキンク帯の形成・成長と関連付けて解釈する。

\footnotetext{
${ }^{1}$ 熊本大学工学部マテリアル工学科（（８60-8555 熊本県熊本市中央区黒髪2-39-1） Department of Materials Science and Engineering, Kumamoto University (2-39-1 Kurokami, Chuo-ku Kumamoto-shi, Kumamoto 860-8555)

2 北見工業大学 (北見市) Kitami Institute of Technology（Kitami-shi, Hokkaido）

* 責任著者E-mail : mayama@kumamoto-u.ac.jp

受付日：2019年10月 16 日 受理日：2020年1月 14 日
} 
10 |||||||||||||||||||||||||||||||||||||||||||||||||||||||||||||||||||||||||||||||||||||||||||||||||||||||||||||||||||||||||||||||||||||||||||||||||||||||||||||||||||||||||||||||||||||||||||||||||||||||||||||||||||||||||||||||||||||||||||||||||||||||||||||||||||||||||||||||||||||||||||||||||||

(a)

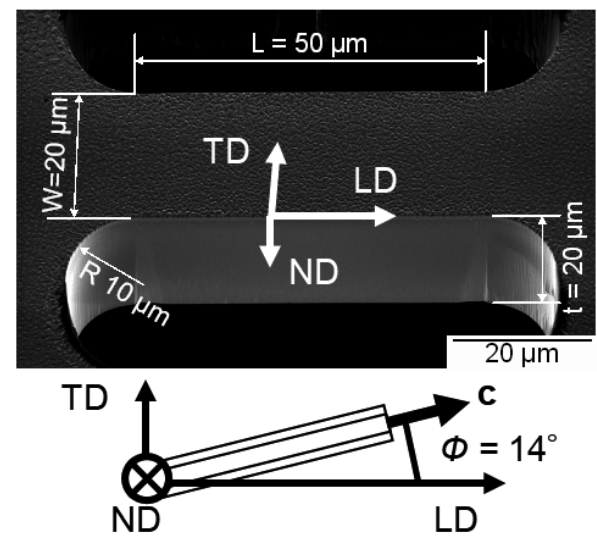

(b)

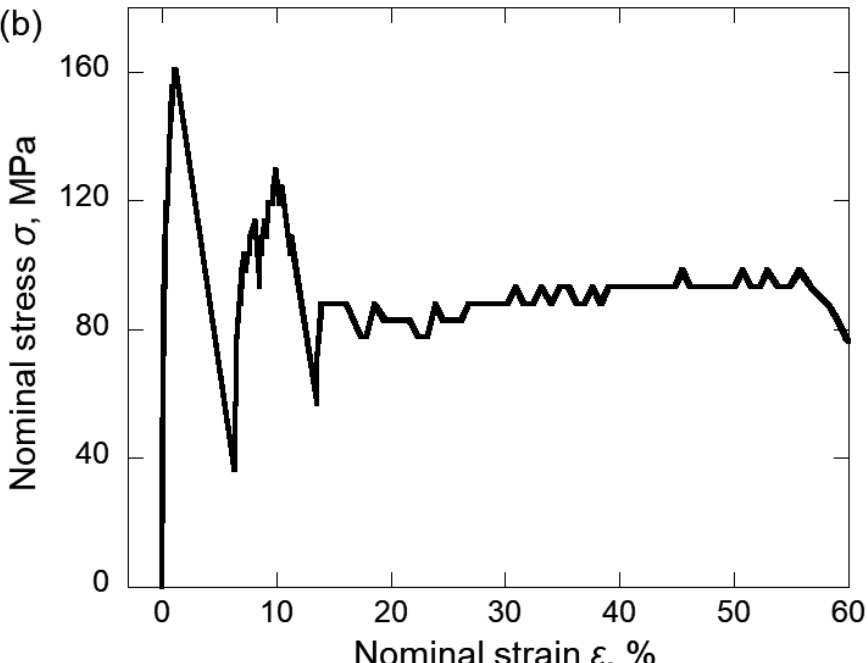

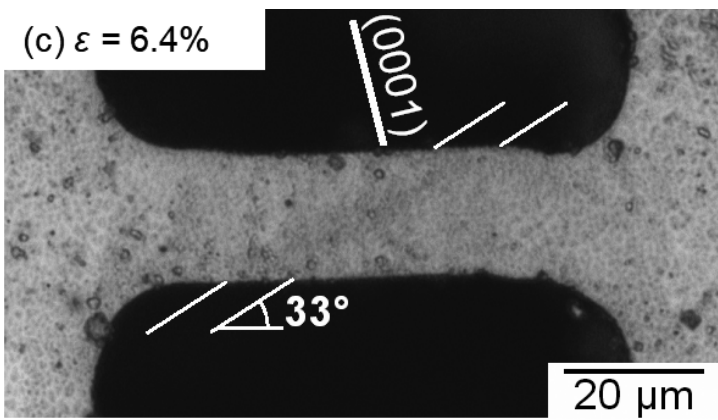

(d)

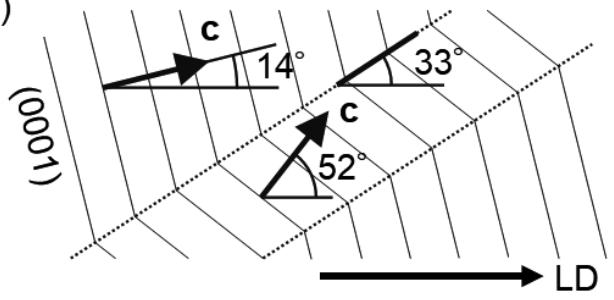

(e) $\varepsilon=57 \%$

図 1 マイクロ引張試験結果 ${ }^{34)}$ 。（a）マイクロ材料試験片，（b）応力ーひずみ曲線，公称ひずみ (c) $6.4 \%$ およ゙ (e) $57 \%$ における光学顕微鏡観察像，（d）公称ひずみ $6.4 \%$ の变形帯をキンク帯と仮定した場合の模式図

\section{1 解析手法・解析モデル}

本解析ではPeirceらにより提案された速度依存型結晶塑性 構成則 ${ }^{24)}$ を導入した大変形有限要素法を用いた。 Mg 基 LPSO 構造は底面の積層と溶質元素の濃化が同期した結晶構造を持 つが, ここでは近似的に $2 \mathrm{H}$ 構造を持つ $\mathrm{HCP}$ 金属と同様に取 り扱うことにする。すべり系 $\alpha$ の剪断ひずみ速度 $\dot{\gamma}^{(\alpha)}$ が次式 で得られると仮定する。

$$
\dot{\gamma}^{(\alpha)}=\dot{\gamma}_{0} \operatorname{sgn}\left(\tau^{(\alpha)}\right)\left|\frac{\tau^{(\alpha)}}{g^{(\alpha)}}\right|^{1 / m}
$$

ここで， $\tau^{(\alpha)}, m$ ，および $\dot{\gamma}_{0}$ は，それぞれすべり系 $\alpha$ の分解剪 断応力, ひずみ速度依存性指数, および参照剪断速度を表す。 速度依存性指数は $m=0.02$ を用いた。臨界分解剪断応力 (CRSS) に対応する参照応力 $g^{(\alpha)}$ の発展則としては, $\mathrm{Mg}$ およ び $\mathrm{Mg}$ 合金の結晶塑性解析でしばしば用いられている以下の モデル ${ }^{35), 36)}$ を使用した。

$$
\dot{g}^{(\alpha)}=\sum_{\beta} \frac{d \hat{\tau}^{(\alpha)}}{d \Gamma} \Omega^{(\alpha \beta)}\left|\dot{\gamma}^{(\beta)}\right|
$$

ここで， $\Omega^{(\alpha \beta)}$ はすべり系間の相互作用を表現する係数である が, 本研究ではすべての組合せで $\Omega^{(\alpha \beta)}=1$ と仮定した。また,
式 (2) 中の $\hat{\tau}^{(\alpha)}$ は, 累積すべり量 $\Gamma$ 関数であるVoce型硬化 則を用いた。

$$
\hat{\tau}^{(\alpha)}=\tau_{0}^{(\alpha)}+\left(\tau_{1}^{(\alpha)}+\theta_{1}^{(\alpha)} \Gamma\right)\left\{1-\exp \left(-\frac{\theta_{0}^{(\alpha)} \Gamma}{\tau_{1}^{(\alpha)}}\right)\right\}
$$

ここで， $\tau_{0}^{(\alpha)}, \tau_{1}^{(\alpha)}, \theta_{0}^{(\alpha)}$ ，および $\theta_{1}^{(\alpha)}$ は材料パラメータであ り，図 1 (b) に示した応力ーひずみ挙動の実験結果に基づき， それぞれ $35 \mathrm{MPa}, 10^{-4} \mathrm{MPa}, 10 \mathrm{MPa}$ ，および $30 \mathrm{MPa}$ と同定 した。なお，今回は実験的に底面すべり系の活動のみが確認 されたため, 数值解析においても底面すべり系のみを考慮し て上記材料パラメータを用いたが，非底面すべり系の活動も 考慮する際には各変形機構に対して材料パラメー夕を同定す る必要がある。弾性特性としてはTane ${ }^{37)}$ が報告している 18R-LPSO 構造を持つ Mg-Zn-Y 合金単結晶の異方性弾性定数 $\left(\mathrm{C}_{11}=67.7 \mathrm{GPa}, \mathrm{C}_{33}=72.9 \mathrm{GPa}, \mathrm{C}_{12}=28.3 \mathrm{GPa}, \mathrm{C}_{13}=19.5 \mathrm{GPa}\right.$, $\mathrm{C}_{44}=21.5 \mathrm{GPa}$ ）を用いた。

図 2 は本解析で用いた解析モデルの模式図を示している。 モデル形状および初期結晶方位はマイクロ材料試験片と一致 させている。この解析モデルに対して, 引張負荷を強制変位 により与えた。 


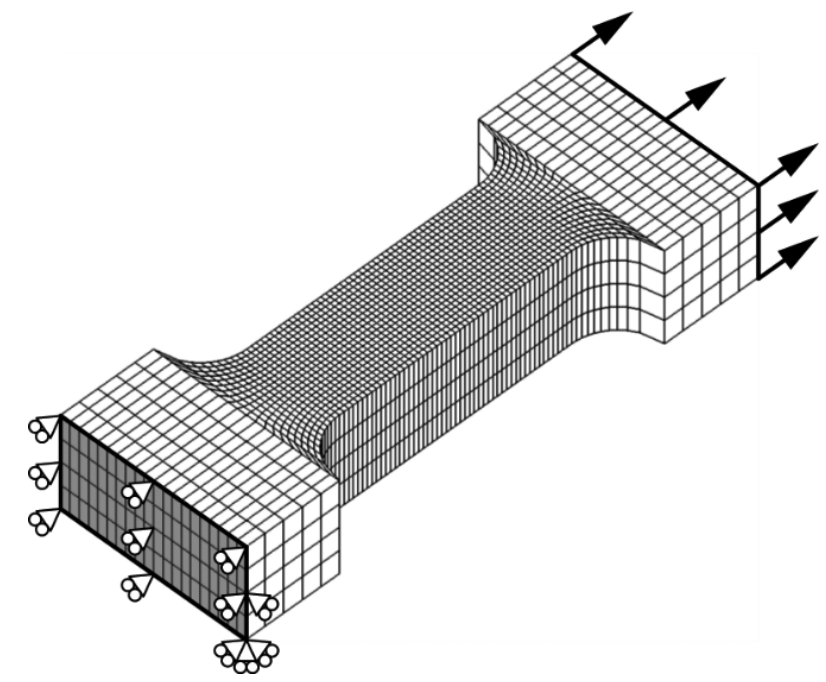

図 2 引張負荷解析モデル ${ }^{34)}$

\section{2 解析結果}

結晶塑性解析により得られた応力ーひずみ曲線を図 $3(a)$ 中に○印で示している。実線で示した実験結果と同様に，降 伏後の急激な応力の低下, およびその後のほぼ一定の流動応 力による変形挙動が再現されている。図3(b) は応力の急激 な低下前後の底面すべり分布を示している。急激な応力低下 直後の $\varepsilon=6 \%$ において, 試料中央から右上および左下に底面 すべりが局所的に累積した帯状の領域が見られ，その領域は 初期結晶方位における底面と垂直に近い領域に分布してい る。これらの特徵は図 $1(\mathrm{~d})$ に示した模式図と同様であり, キ ンクモードのすべりの局所化により形成されたものである。 また，図3(c) は流動応力がほぼ一定のひずみ域における底 面すべり分布の発達を示しており, 変形初期において試料中 央付近に局所化していた底面すべりの累積領域が, 変形に伴 い試料の左右両側に拡大していることがわかる。この拡大過 程においても, 底面すべりの分布はキンク帯の特徴を有して おり，流動応力がほぼ一定のひずみ域における変形はキンク 帯の成長により担われていると表現することもできる。眓3 (c) のひずみ量 $\varepsilon=50 \%$ における変形形状を図 $1(\mathrm{e})$ に示した 実験観察結果と比較すると, 計算結果では試験片中央部から 左右対称にすべりの蓄積箇所が分布しているのに対して, 実 験結果では右側に蓄積箇所がずれている。これは実験的には 不可避的に導入される初期不均一性の有無によるものと考え られる。

\section{3 キンク帯形成機構}

図4(a) の○印は，変形に伴う試料中央における角度 $\Phi$ の 変化を示している。ここで角度 $\Phi$ は, $\mathrm{c}$ 軸と負荷軸間の角度 として定義している。破線で示した応力ーひずみ曲線と角度 Фの変化を比較すると, 変形初期において角度 $\Phi$ は徐々に小 さくなる傾向を示しているが, 応力が急激な低下を示すと同 時に角度 $\Phi$ が著しく増加していることがわかる。図 $4(\mathrm{~b})$ に 示した角度 $\Phi$ 分布からは, 応力の急激な減少後の $\varepsilon=6 \%$ にお いて, 図3(b) で底面すべりの著しい累積を示した領域にお いて角度 $\Phi$ 大ききい值を示していることがわかる。このこと は，底面すべりが結晶格子の大きな回転をもたらしたことを

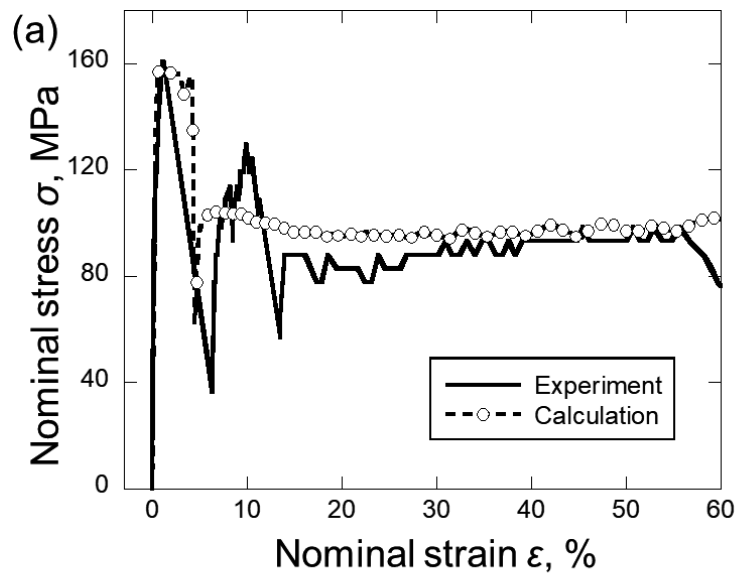

(b)

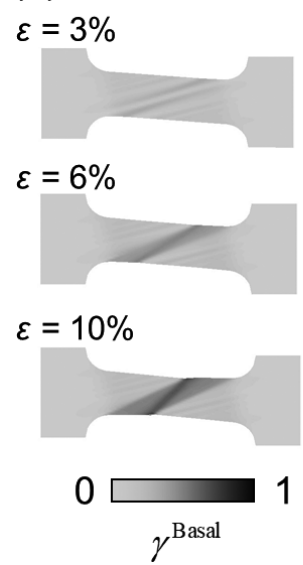

(c)

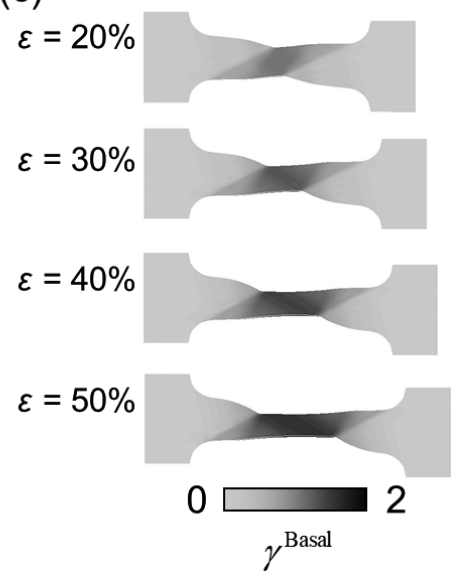

図3 引張負荷解析結果 ${ }^{34)}$ 。(a) 応力-ひずみ挙動, (b), (c) 変形形状と底面すべり分布

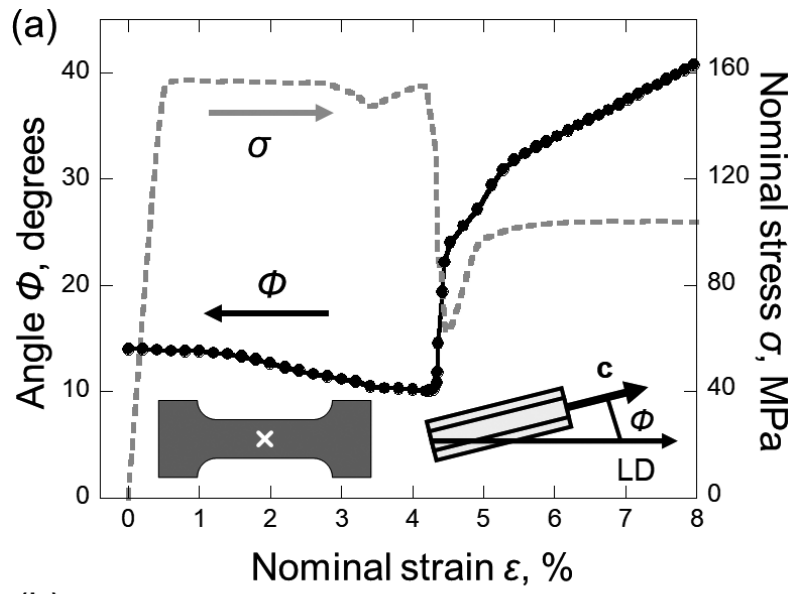

(b)

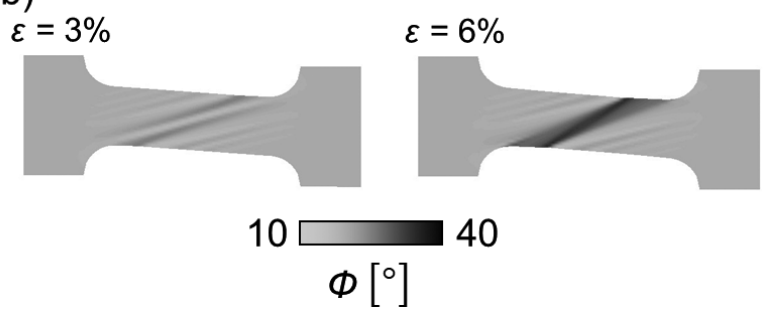

図4 キンク帯形成時の角度 $\Phi$ 変化 ${ }^{34)}$ 。(a) 試料中央部 における角度変化, (b) 角度分布 
(a)

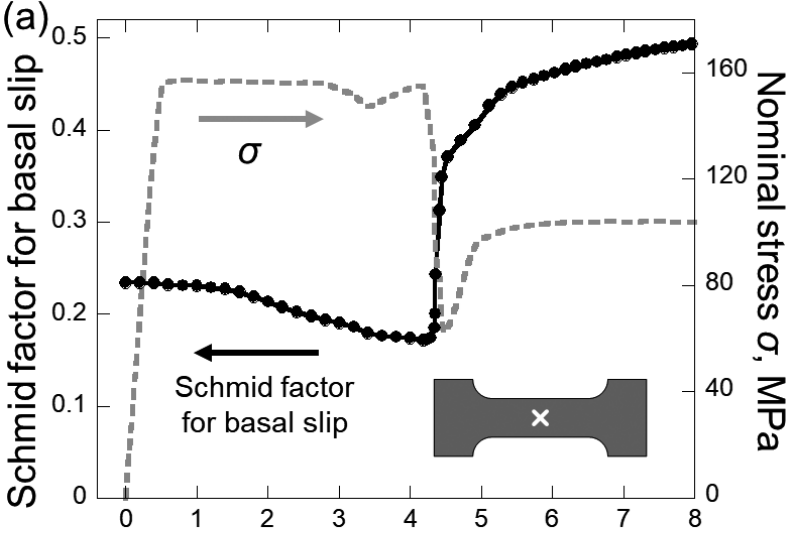

(b)

Nominal strain $\varepsilon, \%$

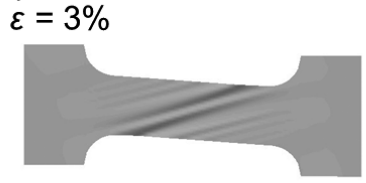

$\varepsilon=6 \%$

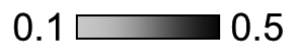

Schmid factor for basal slip

図 5 キンク带形成時のシュミットファクター変化 ${ }^{34)}$ 。 （a）試料中央部に扔ける変化，（b）シュミットファ クター分布

示している。図5(a) の@印は, 変形に伴う試料中央におけ る底面すべり系のシュミットファクター変化を示している。 この図より, 底面すべり系のシュミットファクターも応力の 急激な低下に伴い著しく増加していることがわかる。図 $5(\mathrm{~b})$ に示すシュミットファクター分布も，角度 $\Phi$ 分布と同様の分 布を示している。図4扮よび図 5 より，底面すべりが局所的に 累積した領域における大きな結晶格子回転がシュミットファ クターの著しい増加をもたらし, 図3(a) の応力ーひずみ挙 動に打ける負荷応力の急激な低下が生じたと解釈できる。

\section{4 キンク帯成長機構}

図6(a) は $\varepsilon=10 \%$ から $\varepsilon=50 \%$ に打ける角度 $\Phi$ 分布の変化 を示している。 $\varepsilon=10 \%$ では試料中央付近の狭い帯状領域に 限定されていた角度Фの大きな領域が，変形に伴い左右の領 域に拡大し， $\varepsilon=50 \%$ では試験片平行部全体にわたって大き な角度 $\Phi$ を示している。図6(b) は図6(a) の点0から点1を 結ぶ破線に沿った角度 $\Phi$ ラインプロファイルを示してい る。変形に伴い最大 $60^{\circ}$ 程度まで角度 $\Phi$ 上昇した領域が，試 料中心付近から両側に拡大していることがわかる。図7(a) は $\varepsilon=10 \%$ から $\varepsilon=50 \%$ に打ける底面すべり系のシュミットファ クター分布の変化を示している。 $\varepsilon=10 \%$ では試料中央付近 の帯状領域において最大值を示すのに対して, $\varepsilon=50 \%$ では 試験片平行部の左右端付近に最大領域が移動していることが わかる。図7 (b) は図7 (a) の点0から点1を結ぶ破線に沿っ たシュミットファクターのラインプロファイルを示してい る。この図からも変形に伴い最大シュミットファクターを示 す領域が，試料中央から両側に移動していることがわかる。

図6および図7より, 流動応力がほぼ一定で変形する領域に 拉けるキンク带の成長過程は以下のように説明される。ま (a)

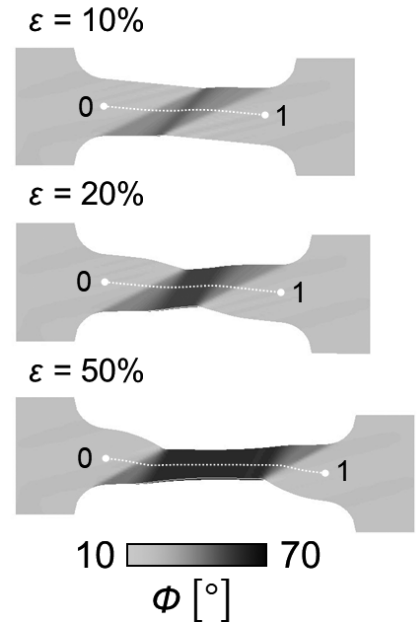

(b)

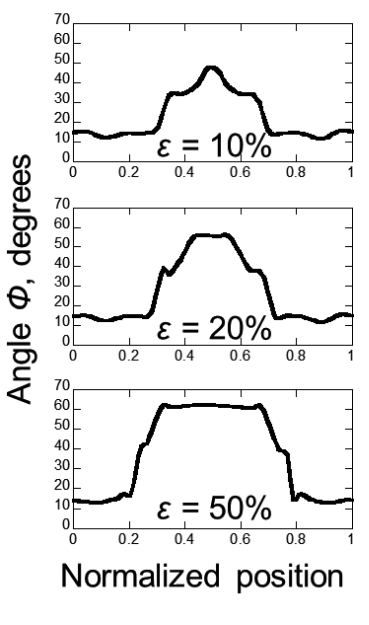

図6 キンク帯成長時の角度 $\Phi$ 発達 ${ }^{34)}$ 。(a) 角度 $\Phi$ 分布, (b) 角度Фのラインプロファイル変化 (a)

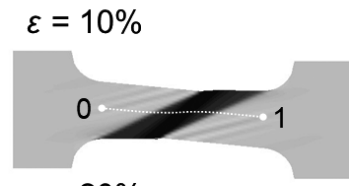

$\varepsilon=20 \%$

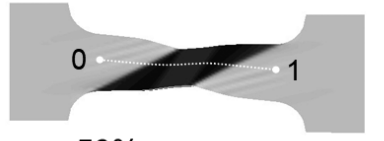

$\varepsilon=50 \%$

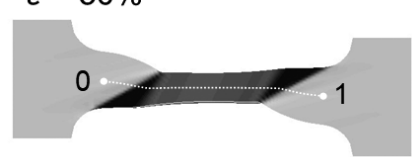

0.2

Schmid factor for basal slip (b)

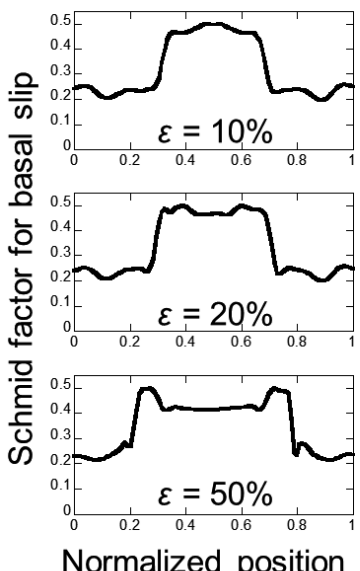

図7 キンク带成長時の底面すべり系シュミットファク 夕ーの変化 ${ }^{34)}$ 。(a) シュミットファクター分布, （b）シュミットファクターのラインプロファイル 変化

ず，試料中央付近に扔ける初期キンク帯では，周辺領域より もシュミットファクターが大きいため底面すべりが継続す る。その後，さらなる結晶格子回転によりシュミットファク ターが低下すると，シュミットファクターが最大となった隣 接領域の底面すべり系の活動が顕著となる。この隣接領域へ の活動領域の移動は，試料中心付近から左右両側に伝播す る。このようなキンク帯の成長により，すべりの過度な累積 に起因する早期破壊が回避され，今回の負荷方向に扔ける高 い延性の発現に至ったものと考えられる。

\section{3. 剪断負荷を受ける単結晶におけるキンク帯形成 解析}

剪断負荷は素形材製造過程において不可避的に付与される 負荷モードである。LPSO型Mg合金が塑性加工により高強度 を発現することから，剪断負荷下に扔けるキンク帯形成に関 
する理解は重要である。そこで本章では，初期不均一性を有 する $\mathrm{Mg}$ 基LPSO相を対象として, 純粋剪断負荷を受けた際の キンク帯形成過程を数值的に調査した結果を紹介する。

\section{1 解析手法・解析モデル}

本章の解析においても2.1節に示した結晶塑性有限要素法 を用いた数值解析を実施したが，解析結果の評価指標として 幾何学的に必要な $(\mathrm{GN})$ 転位密度 ${ }^{38)}$ を用いた。すべり系 $\alpha$ の GN 転位密度は, 結晶塑性有限要素解析により得られるすべ り量 $\gamma^{(\alpha)}$ の空間分布を用いて見積もられる量であり，その刃 状成分 $\rho_{\mathrm{GNDedge}}^{(\alpha)}$ およびらせん成分 $\rho_{\mathrm{GNDscrew}}^{(\alpha)}$ は次式により定義さ れる。

$$
\rho_{\mathrm{GNDedge}}^{(\alpha)}=-\frac{1}{\tilde{b}} \frac{\partial \gamma^{(\alpha)}}{\partial \xi^{(\alpha)}}, \quad \rho_{\mathrm{GNDscrew}}^{(\alpha)}=\frac{1}{\tilde{b}} \frac{\partial \gamma^{(\alpha)}}{\partial \zeta^{(\alpha)}}
$$

ここで， $\tilde{b}$ はバーガースベクトルの大きさ， $\xi^{(\alpha)}$ および $\zeta^{(\alpha)}$ は，それぞれすべり面上ですべり方向に平行な方向と垂直な 方向である。

図８は単結晶モデルによる純粋剪断解析の模式図を示して いる。試料寸法は, $20 \times 20 \times 1 \mu \mathrm{m}$ の板状とし， 20 節点 8 積分 点ソリッド要素で均一に要素分割している。初期結晶方位 は， $x-y$ 平面と柱面が平行であり，さらに $\mathrm{c}$ 軸と $x$ 軸方向を一 致させた方位とした。純粋剪断負荷においてキンク帯が形成 されるためには，その起点となり得る何らかの初期不均一性 を導入する必要がある。本解析では初期不均一性として底面 すべり系の初期 CRSSが周囲（以下，マトリックス）よりも 低い円状領域（以下，軟質領域）を試料中心部に配置した。 不均一領域の精密な形状に本質的な重要性はないのでここで はボクセルモデルを用いて領域形状を与えている。ただし 3.2 節の最後に触れるように, 不均一領域の大まかな形状（広 がり方）とキンク帯形成には密接な関係がある。本稿では等 方的な形状である円状領域の場合について述べる。

この試料の $x$ 軸および $y$ 軸に垂直な側面に純粋 $x-y$ 剪断変形 となる方向に変位を与えた。以上の条件で変形解析を実施す ると, 塑性変形はすべり方向が $y$ 軸方向と一致する底面す心゙ り系が支配的に活動し，他のすべり方向を有する底面すべり 系 2 モードはほとんど活動しない。以降では，支配的に活動 した底面すべり系の GN 転位密度やすべり量のみを示す。

\section{2 解析結果}

図9および図 10 は解析により得られた底面すべり系の GN 転位刃状成分密度の発達を示している。図9の剪断ひずみ $\varepsilon_{x}$

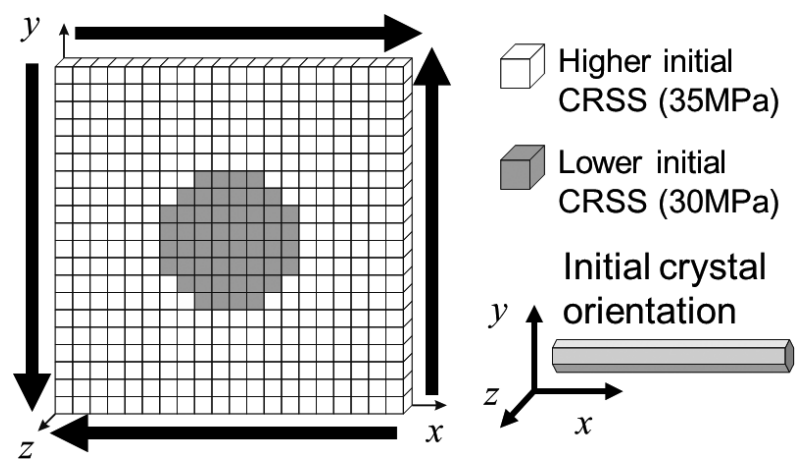

図8 純粋剪断解析モデル

$=0.07 \%$ においてマトリックス/軟質領域界面近傍に GN 転 位密度の高い領域が現れ，さらに剪断ひずみ量が増加する と，図10に示すようにマトリックス領域内においても GN 転 位密度の高い帯状領域が形成されている。剪断ひずみ $\varepsilon_{x y}=$ $0.3 \%$ においては, 底面に対して垂直な方向にGN転位帯が正 負対となって形成されている。

図11(a)，(b) は，それぞれ底面すべり分布および剪断応力
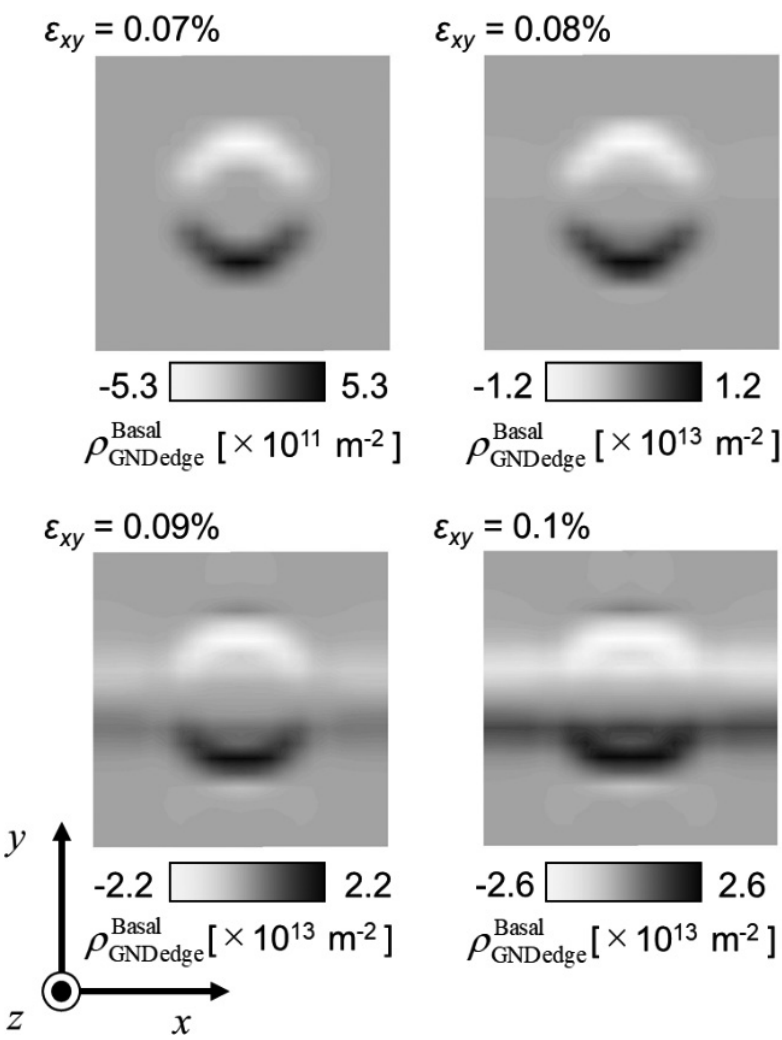

$\varepsilon_{x y}=0.1 \%$

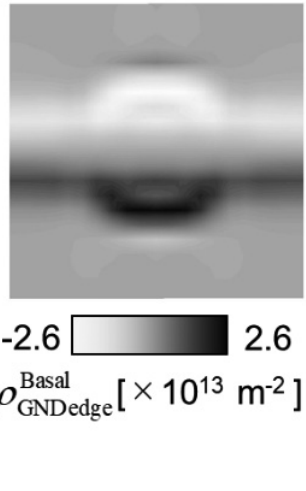

図9 変形初期における底面すべり系の GN 転位密度分 布発達

$\varepsilon_{x y}=0.1 \%$
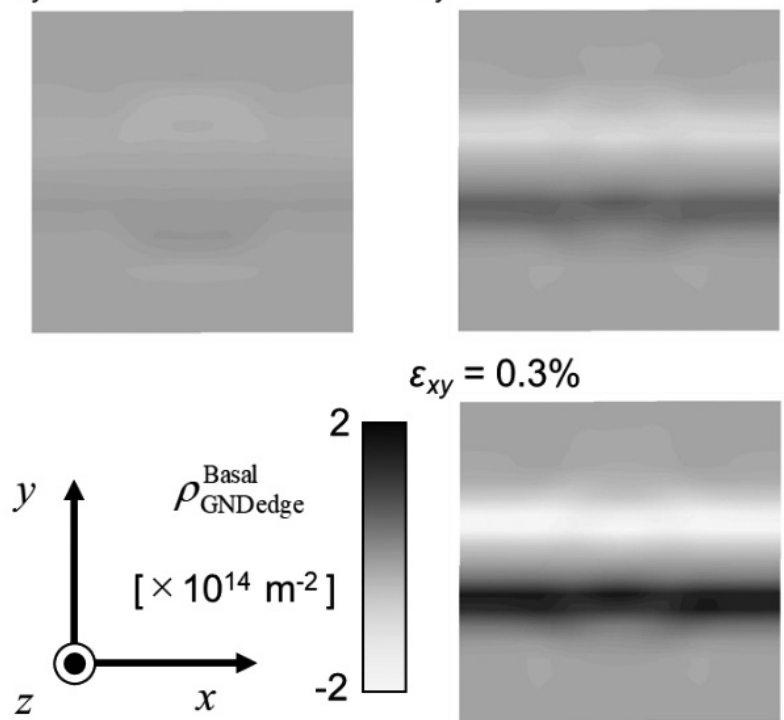

図10 キンク帯形成を示す底面すべり系の GN 転位密度 分布発達 
$\tau_{x y}$ 分布の発達を示している。変形初期 $\varepsilon_{x y}=0.08 \%$ において, 軟質領域に集中していた底面すべりが，剪断ひずみの増加に 伴い軟質領域の上下左右へも累積している。これは, 軟質層 の塑性変形により応力分布が不均一になったことにより, 図 11 (b) に示すように, 剪断応力 $\tau_{x y}$ が軟質領域の上下左右で比 較的高くなったことによる。底面すべりの分布が剪断方向に 沿って不均一になった結果, GN転位の刃状成分が図 9 , 図 10 に示したように発達したものと考えられる。

図 8 に示した初期結晶方位と図 11 (a) に示した $\varepsilon_{x y}=0.3 \%$ に おける底面すべりの分布より, 支配的に活動している底面す ベり系の剪断方向と垂直に, 周囲よりもすべり量の大きな領 域が広がっており, キンク帯に相当するひずみの局所化領域 としての特徴を示している。また,このキンク帯は図10に示 したGN刃状転位帯に挟まれた領域としても表現することが できる。

図11(a) に示されているように, 底面すべりが大きくなっ た領域は軟質領域から上下に伸びる帯状領域にも広がってい る。塑性剪断ひずみが大きな領域が帯状に広がり, その帯の 伸びる方向がバーガースベクトルの方向（この場合はy軸に

(a)

$\varepsilon_{x y}=0.08 \%$

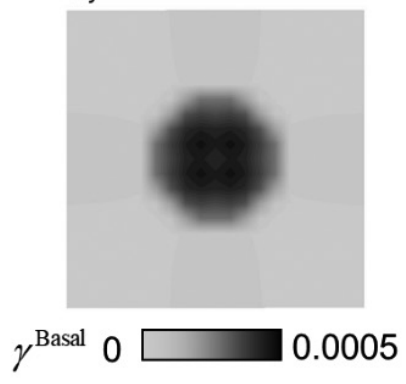

(b) $\varepsilon_{x y}=0.08 \%$

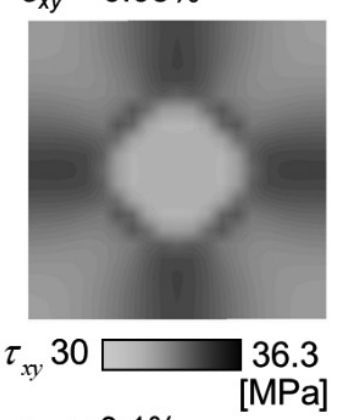

$$
\varepsilon_{x y}=0.1 \%
$$
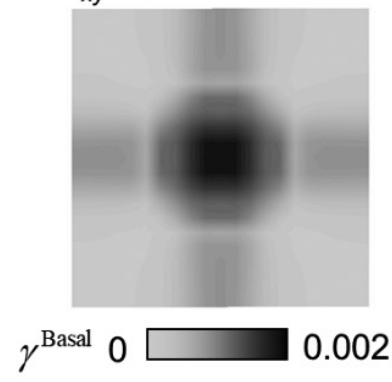

$$
\varepsilon_{x y}=0.1 \%
$$

[MPa]

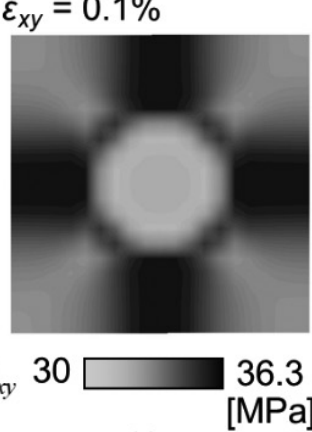

$$
\varepsilon_{x y}=0.3 \%
$$

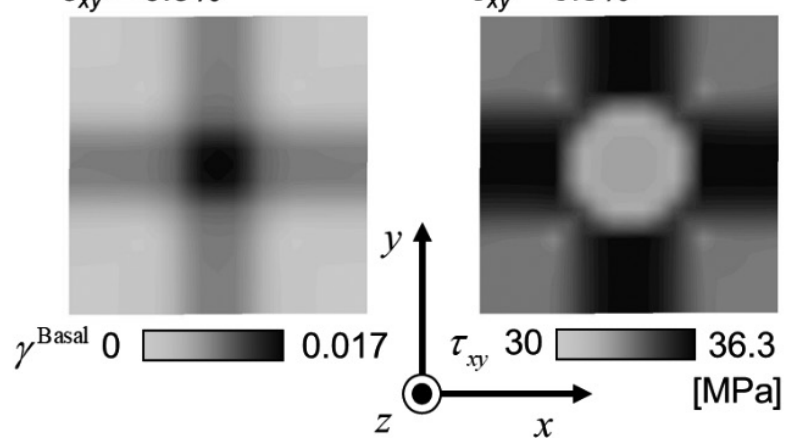

図 11 塑性変形に伴う（a）底面すべり分布および（b) 剪断応力分布の変化
平行な方向）に近い時, このような変形領域は一般的に剪断 帯と呼ばれる。すなわち, 図 11 (a) に見られる上下方向に伸 びる帯状領域は剪断帯に相当するものである。この場合, 塑 性剪断ひずみの空間的な勾配（バーガースベクトル方向の勾 配）は小さいので顕著な GN 転位の蓄積は起きない。

図12(a)は, マトリックス中に軟質領域を10か所配置した 解析モデルに対して実施した純粋剪断解析の結果を示してい る。剪断ひずみの増加に伴い, 多数の高密度 GN刃状転位帯 が形成することがわかる。これらはいずれも, 図10に示した GN 転位帯と同様にキンク帯に相当するものである。

以上では，円状不均一領域を含む板状モデルを用いたキン ク帯形成を示したが, その形成は不均一領域の形状に強く依 存する。たとえば, 不均一領域の形状を円状から楕円状にす ると, 剪断負荷のもとで形成される変形帯は楕円の長軸方向 と $c$ 軸方向との角度に依存して, 剪断帯またはキンク帯が卓 越したもの, それらの混在するものなど様々に変化する。ま た図8に示した板状モデルから離れ，z軸方向の寸法を大きく してゆくと，観察される現象はさらに複雑になる。さらにま た, 初期結晶方位もキンク帯形成に著しい影響を及ぼす。剪 断負荷下におけるキンク帯形成の詳細な理解には, さらに系 統的な数值解析が必要である。

\section{4. おわりに}

本稿では Mg 基LPSO相において頻繁に観察される, 大きな 粒内方位差の発達を伴うキンク帯の形成過程に関する結晶塑 性有限要素解析について紹介した。本解析ではLPSO相単結 晶を対象としたが, 軽量構造材料として応用される際に有用

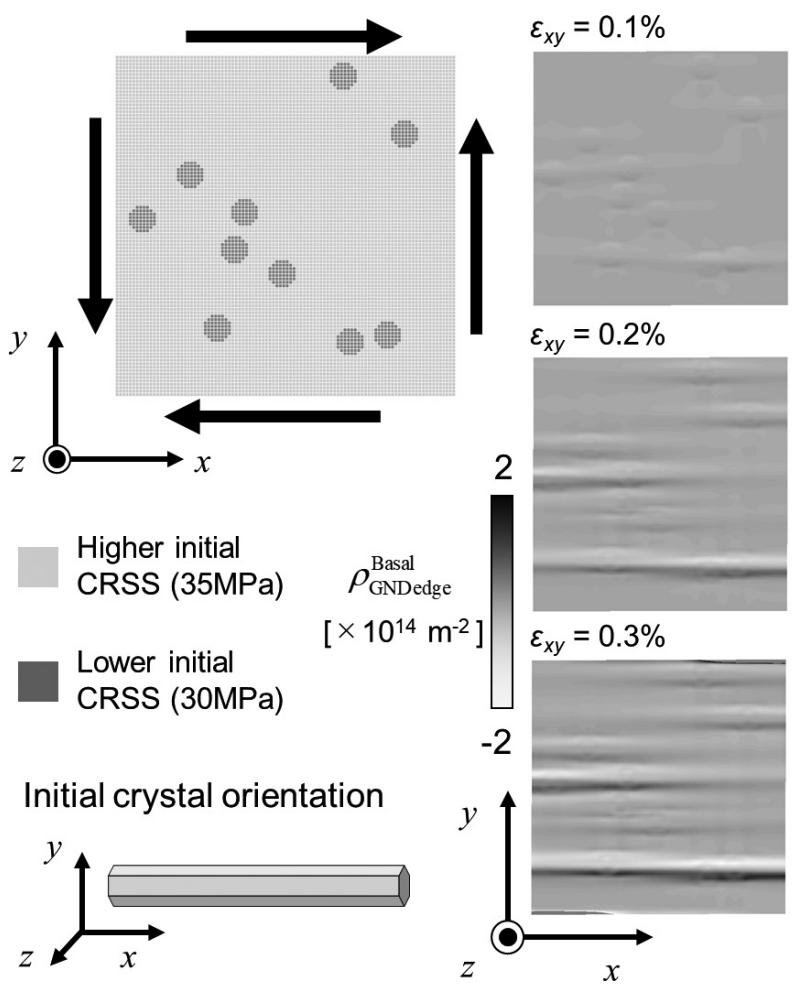

図12 複数の不均一性を含むモデルを用いた純粋剪断 解析の結果 
な知見を得るためには, $\alpha-\mathrm{Mg} / \mathrm{LPSO}$ 二相合金多結晶体の変形 を対象として，さまざまな影響因子の寄与を調べる必要があ る。そのためには, 加工硬化則の精密化, 寸法依存性の考慮, さらには材料パラメータの系統的な同定手法の確立等，検討 すべき課題は多い。

一方，Mg基LPSO相におけるキンク帯の多くはその界面が 非常にシャープであり，界面近傍で急激な結晶方位変化を示 す。また, いったん形成されたキンク帯が後続負荷を受けて も容易に移動や消滅はせず，それ故に力学特性に影響を及ぼ していると考えられる。このような現象を本質的に理解する ためには，溶質元素の影響を含めた原子スケール挙動の把握 が不可欠であると考えられる。さらに，電子顕微鏡観察や原 子シミュレーション等から得られる知見を結晶塑性解析に取 り込み，巨視的な力学挙動を定量的に再現することも挑戦的 な課題である。

\section{謝 辞}

本稿で紹介した内容の一部は, 科学研究費補助金新学術領 域研究「ミルフィーユ構造の材料科学」(18H05480, 19H05133）拈よび「シンクロ型LPSO 構造の材料科学」 (23109009, 26109717）の補助を受けて実施しました。また, 本稿の第 2 章で紹介した引張負荷下におけるキンク帯形成の 共同研究者であり，本稿執筆においてもデー夕を提供して頂 いた熊本大学の高木康介氏，峯洋二教授，高島和希教授およ びUniversity of BirminghamのDr. Y. L. Chiuに謝意を表します。

\section{参 考 文 献}

1) Y. Kawamura, K. Hayashi, A. Inoue and T. Masumoto: Mater. Trans., 42 (2001), 1172-1176, 10.2320/matertrans.42.1172

2) S. Yoshimoto, M. Yamasaki and Y. Kawamura: Mater. Trans., 47 (2006), 959-965.

3) M. Yamasaki, M. Sasaki, M. Nishijima, K. Hiraga and Y. Kawamura: Acta Mater., 55 (2007), 6798-6805.

4) マグネシウム加工技術, 日本塑性加工学会編, コロナ社, (2004).

5) K. Hagihara, Z. Li, M. Yamasaki, Y. Kawamura and T. Nakano: Acta Mater., 163 (2019), 226-239.

6) K. Hagihara, M. Yamasaki, Y. Kawamura and T. Nakano: Mater. Sci. Eng. A, 763 (2019), 138163.

7) R.J. Asaro and J. Rice: J. Mech. Phys. Solids, 25 (1977), 309-338.

8) E. Orowan: Nature, 149 (1942), 643-644.

9) J.B. Hess and C.S. Barrett: Metals Trans., 185 (1949) 599-606

10) J.J. Gilman: Trans. AIME, 200 (1954), 621-629.

11) H. Yoshinaga and R. Horiuchi: Trans. JIM, 3 (1962), 220-226.
12) A.G. Zhou, S. Basu and M.W. Barsoum: Acta Mater., 56 (2008), 60-67.

13) K. Hagihara, T. Mayama, M. Honnami, M. Yamasaki, H. Izuno, T. Okamoto, T. Ohashi, T. Nakano and Y. Kawamura: Int. J. Plasticity, 77 (2016), 174-191.

14) A.G. Evans and W.F. Adler: Acta Metall., 26 (1978), 725-738.

15) B. Budiansky and N.A. Fleck: J. Mech. Phys. Solids, 41 (1993), 183211.

16) S. Narayanan and L.S. Schadler: Composites Sci. Tech., 59 (1999), 2201-2213.

17) T.J. Vogler and S. Kyriakides: Int. J. Solids Struct., 38 (2001), 26392651.

18) M.A. Wadee and R. Edmunds: J. Mech. Phys. Solids, 53 (2005), 20172035 .

19) T.J. Nizolek, M.R. Begley, R.J. McCabe, J.T. Avallone, N.A. Mara, I.J. Beyerlein and T.M. Pollock: Acta Mater., 133 (2017), 303-315.

20) L. Zhao, Q. Guo, Z. Li, D.-B. Xiong, S. Osovski, Y. Su and D. Zhang: Int. J. Plasticity, 116 (2019), 265-279.

21) C.S. Barrett and L.H. Levenson: Trans. AIME, 135 (1939), 327-352.

22) R.W. Cahn: J. Inst. Metals, 79 (1951), 129-158.

23) K. Higashida, J. Takamura and N. Narita: Mater. Sci. Eng., 81 (1986), 239-258.

24) D. Peirce, R. J. Asaro and A. Needleman: Acta Metall., 31 (1983), 1951-1976.

25）黑田充紀，志澤一之：塑性と加工, 43 (2002)， 299-309.

26) F. Roters, P. Eisenlohr, L. Hatcherli, D.D. Tjahjanto, T.R. Bieler and D. Raabe: Acta Mater., 58 (2010), 1152-1211.

27) T. Ohashi: Mater. Trans., 31 (1990), 456-462.

28) S. Forest: Acta Mater., 46 (1998), 3265-3281.

29) T. Mayama, T. Ohashi, Y. Tadano and K. Hagihara: Mater. Trans., 56 (2015), 963-972.

30) Y. Kimura, R. Ueta and K. Shizawa: Procedia Manuf., 15 (2018), 1825-1832.

31) Y. Mine, R. Maezono, H. Oda, M. Yamasaki, Y. Kawamura and K. Takashima: Mater. Trans., 56 (2015), 952-956.

32) Y. Mine, K. Koga, O. Kraft and K. Takashima: Scr. Mater., 113 (2016), 176-179.

33) Y. Mine, S. Nakamichi, K. Koga, K. Takashima and O. Kraft: Mater. Sci. Eng. A, 675 (2016), 181-191.

34) K. Takagi, T. Mayama, Y. Mine, Y.L. Chiu and K. Takashima: J. Alloys Compounds, 806 (2019), 1384-1393.

35) S.R. Agnew, M.H. Yoo and C.N. Tomé: Acta Mater. 49 (2001), 4277 4289.

36) A. Prakash, S.M. Weygand and H. Riedel: Comp. Mater. Sci. 45 (2009), 744-750.

37) M. Tane, Y. Nagai, H. Kimizuka, K. Hagihara and Y. Kawamura: Acta Mater., 61 (2013), 6338-6351.

38) T. Ohashi: Philos. Mag. Letters, 75 (1997), 51-57. 